\title{
Thyroid Gland Immunoblastic Lymphoma
}

National Cancer Institute

\section{Source}

National Cancer Institute. Thyroid Gland Immunoblastic Lymphoma. NCI Thesaurus.

Code C7263.

A diffuse large B-cell lymphoma variant, primarily involving the thyroid gland. It is composed predominantly of immunoblasts. 